\title{
The Evolution of Tariff Protection and Wage Protection in the Late Colonies and Early Federation
}

\author{
by
}

Peter Lloyd

Abstract

This paper examines the links between tariff protection and wage protection These two areas of regulation were linked politically by a coalition of the Protectionist Party and the Labour Party which supported both policies together. In the regulatory systems themselves there were links through New Protection Policy and the major influence it had on the hugely important Harvester Judgment of the Court of Conciliation and Arbitration. By 1910, these developments had laid down the foundations of Australian tariff policy and labour market regulation which became among the most highly regulated markets in the non-communist world for many decades.

Key words: tariff protection, New Protection Policy, Harvester Judgment, links, wage protection, Short running title: Evolution of Tariff and Wage Protection

Acknowledgments. I would like to thank Robert Dixon, Jeff Borland,Mark Wooden and two referees for their very helpful comments on a draft.

Address for Correspondence:

Department of Economics,

University of Melbourne,

Parkville, Vic. 3010,

Australia

Phone: 61383445291

Fax: 61383446899

Email: pjlloyd@unimelb.edu.au

This is the author manuscript accepted for publication and has undergone full peer review but has not been through the copyediting, typesetting, pagination and proofreading process, which may lead to differences between this version and the Version of Record. Please cite this article as doi: $10.1111 / 1759-3441.12183$

This article is protected by copyright. All rights reserved 
Article type : Review

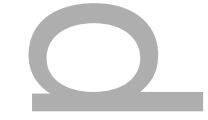

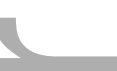

The Evolution of Tariff Protection and Wage Protection in the Late Colonies and Early Federation

1. Introduction

In the first decade after Federation the Australian Parliament passed legislation that determined the main features of our economic and social policies and institutions in several areas. The historian Francis Castles (1988) asserted there were four areas of "closely interrelated" economic and social policies: the protection of manufacturing industry through tariffs and other trade restrictions, the conciliation and arbitration of industrial disputes, the control of immigration, and a residual system of income maintenance for those outside the labour market (Castles, 1988, p. 93). He called this set of policies "domestic defence" or "social protection" They were supported by what he termed a "historic compromise" of the political parties. A few years later Kelly (1992, Introduction) put forward a similar characterisation which he called "the Australian Settlement". He describes the settlement as covering five headings - White Australia, Industry Protection, Wage Arbitration, State Paternalism and Imperial Benevolence. In his view there was a consensus between the political parties of the time which accepted these principles - hence the "settlement." Both authors assert that these policies continued to operate for many decades.

The Domestic Defence/Australian Settlement characterisation of early Commonwealth legislation is a powerful concept that deals with very important features of our economic and social history. Yet, the four/five elements were never presented by the enacting parliamentarians as a package and this characterisation has not been widely adopted by historians. ${ }^{1}$

\footnotetext{
${ }^{1}$ There is, for example, no reference to the Australian Settlement in the recent Cambridge Economic History of Australia. There are only brief and mixed references to it in the new Cambridge History of Australia. The notion of an Australian Settlement has been strongly criticised by Stuart Macintyre (2009), Fenna (2012) and other historians and social scientists.
} 
Two of the elements, however, were closely connected. These are the protection of manufacturing industry through tariffs and other trade restrictions and the conciliation and arbitration of industrial disputes. These two areas were often referred to as "tariff protection" and "wage protection". The aim of this paper is draw out the links between these two areas and to show how they led to the foundation legislation and institutions.

After federation, the Parliament had to move immediately to fix the uniform rates on individual tariff items which were required by the constitution. This was done in the 1902 Customs Tariff Act. These rates were fixed mainly on the basis of the revenue needs of the new Commonwealth (Lloyd 2015). For the next five years there was an intense conflict in Parliament between those parliamentarians who wanted a free trade policy and the protectionists who were dissatisfied with the levels of protection in the 1902 Tariff. At the instigation of the protectionist Members of Parliament, a Royal Commission on Customs and Excise Tariffs was called to examine the workings of the 1902 Customs and Excise Acts. This recommended an increase in some rates. Finally, it was the Customs Tariff Act 1908, the so-called Lyne Tariff, which set the Commonwealth on a path of higher protection of manufacturing industries.

A bill relating to compulsory arbitration was tabled in Parliament in 1901 but the Commonwealth Conciliation and Arbitration Act was not passed until 1904. There was a major conflict in Parliament over this legislation too, second only to that over tariff protection. It related to issues such as whether the legislation should cover public servants of the States and Commonwealth, compulsory arbitration, and work preference for union members.

There was a major link between the two areas of tariff protection and wage protection in Alfred Deakin's New Protection Policy of 1906. The link took the form of measures to try to ensure that the producers who received protection paid fair and reasonable wages to their employees. New Protection Policy had a further major influence on the hugely important 1907 Harvester Judgment of the newly-created Court of Conciliation and Arbitration. This Judgment converted the abstract notion in New Protection of a "fair and reasonable wage" into an operational statisticallydetermined "living wage".

La Nauze (1965, p. 436) states that by 1910 all of the parliamentary parties had proclaimed their support for New Protection. Thus, only a decade after federation, there was acceptance by the two major parties of tariff protection and of centralised wage-fixing by the Conciliation and Arbitration Court. 
This bi-partisan acceptance by politicians of the foundation policies of tariff protection and wage protection continued for many decades After 1910 in the Commonwealth Parliament there was no champion of free trade, no one like the New South Welshman (Sir) George Reid in the first decade, until the emergence of the maverick Bert Kelly in the Sixties. As a general policy goal, tariff protection was not challenged by politicians until the Hawke Government. (See Castles (1988) and Paul Kelly (1992) for similar accounts of the breakdown of the previous consensus).

Academic economists in Australia accepted tariff protection until after World War II. The Brigden Committee economists (three of whom had academic positions) accepted the policy of protection in the past and came up with a novel argument that protection had enabled the country to sustain a larger population. But the Committee judged that protection had reached its "safe" limits and noted that the burden was born by unprotected export industries. There were criticisms of protection policy by Shann (1930) and Hancock (1930) on practical grounds. Shann emphasised that the system of protection tends to spread among producers, leading to "overall protection," including assistance to agricultural producers. The questioning of protection as a policy goal began in the 1960s with the work of academic economists such as Max Corden on the costs of protection. Latter day Tariff Board Chairmen (Sir) Leslie Melville and Alf Rattigan in the 1960s and 1970s became increasingly critical of government tariff policy which precipitated major conflicts with politicians, especially the arch-protectionist Minister of Trade, Sir Jack McEwen.

The Conciliation and Arbitration Act led to a highly centralised system of wage-fixing whose main features persisted in Australia until the 1980s. (See Borland, 2015, pp. 433-44). This system of wage fixing was not seriously challenged in Parliament until the introduction of enterprise bargaining in the Nineties. Academic economists and industrial relations specialists in Australia have generally been much more accepting of the regulation of labour markets. (Hancock 2013, Chapter 13 discusses the opinion of economists from the inception of the Commonwealth system up to 1939.) One early academic economist to criticise the system severely was the economic historian Ed Shann (1930, Chapter 21))

In addition, the debates in parliament on "tariff protection" and "wage protection" had a large effect on the formation of the major political parties in Australia. The Free Trade Party and the Protectionist Party began as single-issue parties. The Free Trade Party was renamed the AntiSocialist Party before the 1906 election. The Leader of these two Parties, Sir George Reid, retired in 1908 and the Free Trade Party was dissolved in 1909. In 1910 the Liberal Party was formed by combining Deakin's Protectionist group with the remnants of its former parliamentary adversary, 
the Free Trade Party. In the same year the first majority Labour Government was formed, led by Andrew Fisher. This year marks the beginning of the two-party system in Australian politics (Strangio and Dyrenfurth 2009).

Given the long-lasting effect of legislation passed in the first decade of federation on Australian institutions and policies in these two areas of "tariff protection" and "wage protection" and its effect on the political parties, the history of the links between them needs to be explored. The individual events are, with a few exceptions, well-known but some parts of the story have not been joined. My focus is on the evolution of the institutions in the areas of border protection of goods and labour market regulation and the laws that introduced them. Indeed, this paper could be subtitled "How Australia Got the Foundation Systems of Tariff and Wage Protection". The period covered is that of the late colonial period and the first two decades of the commonwealth.

After the Introduction, Sections 2 and 3 trace the evolution of tariff policy and of labour market regulation respectively in the colonies. This is necessary because the colonial regulations largely determined the forms of the later Commonwealth regulations in these two areas. In fact, the provisions laying down the form of arbitration of industrial disputes in the Conciliation and Arbitration Act 1904 all follow the precedents in the legislation of the colonies of South Australia, New South Wales and Western Australia, and the tariff rates of the 1908 Lyne Tariff restored tariff levels to those that prevailed in the 1890 Victorian Customs Act. Section 4 then traces the evolution of the two areas of regulation in the Commonwealth period up to 1920 , concentrating on the first formative decade which shaped the Commonwealth institutions and laws in the areas of tariff and wages policies-Section 5 provides a political economy explanation of how a coalition of political interests brought about these foundation systems. Brief comments on tariff protection and wage protection in the period after the first two decades of the Commonwealth are made in Section 6. A summary of the various links between tariff protection and wage protection is provided in Section 7 .

\section{Tariff Protection in the Colonies}

The history of tariffs in the colonies is now well-known. Patterson (1968) gives a detailed account of this history. Lloyd (2016) examines the motives for levying tariffs and calculates time series of the average annual tariff rate in each colony.

Throughout the century, revenue-raising was the dominant motive. Until almost the end of the century, revenue from tariffs on imported alcoholic beverages accounted for more than one half of the total colony-wide tariff revenue. 
1866 was the turning point in colonial tariff policy. In that year Victoria passed the 1866 Customs Act. This added to the dutiable items a wide range of goods and all were subject to an ad valorem rate of duty of 10 per cent. Almost all of the dutiable items were manufactured goods. Economic historians have generally agreed that the tariffs in the 1866 Act were a result of the end of the gold rush in the colony at the end of the decade of the 1850s. Beginning in 1861 net migration into the colony by sea became negative and protectionist sentiment grew. In 1858 the Victorian association for the Protection of Native Industry was formed, followed by the Tariff League in 1959. The tariffs were intended to provide employment for surplus miners in order to prevent a population exodus.

Lloyd (2016) calculated a series of the average tariff rate in Victoria from 1852 to 1900. This series shows that the average rate jumped by 5 percentage points in 1867, after the new Act became effective from 6 February 1867.

The 1866 Act was a milestone for protection in Australian history more broadly as it provided protection to manufactures on a scale not previously seen in any colony. After this date, all colonies except New South Wales followed Victoria in adopting more tariffs for protective purposes as distinct from revenue raising. Victoria became known as the "protective" colony and New South Wales as the "free trade" colony. The other colonies were protective to varying degrees.

In the present context, the important question relating to colonial tariffs is the effects of protectionism in Victoria on employment in that colony. There was an intense debate in the last quarter of the $19^{\text {th }}$ century in Victoria (and New South Wales) among politicians on this question. It has been examined by several economic historians in the $19^{\text {th }}$ and $20^{\text {th }}$ centuries. The evidence is mixed.

Both Coghlan (1918, p. 1153) and Shann (1933, p. 318) noted that in the ten years from 1864 to 1874 total employment in Victorian manufactories increased fourfold. It continued to increase in every year until the end of the century, with the exception of the depression years of 1879 and the the mid-Nineties. Coghlan, Shann and also Sinclair (1955) all concluded that Victoria's protectionist policy did stimulate employment in manufacturing industries.

However, Shann (1933, p. 318) noted a major difficulty in interpreting these results: in spite of the comprehensive protection in Victoria, total employment in manufactories in New South Wales, the "free trade" colony, had exceeded that in Victoria, the "protectionist" colony, by the end of the 
century. ${ }^{2}$ This suggested to Patterson (1968, chapter 11) that factors other than tariffs determined employment growth. He notes the influence of trade cycles and of falling import prices. One should note too the factor of population growth: the population of new south Wales passed that of Victoria soon after the 1891 census (Vamplew 1987, pp. 26,27).

One needs to look at the distribution of tariff rates and of employment by industry. Unfortunately, it is not practicable to construct time series of the levels of tariffs for individual industries from the colonial data. Perhaps the best indicator of the effects of this pattern of tariff protection on employment is a comparison of the size of major industries in Victoria and in New South Wales.

Of particular interest in the present context are the Clothing and the Boots and Shoes industries. These two groups figure prominently in the small group of industries whose employees were protected by Victorian Wage Boards in the 1890s. Data published in the Statistical Register for Victoria shows that, in 1890 , the Clothing industry accounted for 9.5 per cent of the total number of hands employed in Victorian manufactories and works, and Boots and Shoes for 6.5 per cent, together making up 16 per cent. By 1900 the total number of hands employed in Clothing alone had grown to 19,463 or 30.3 per cent of the total manufacturing employment. Moreover, the Clothing industry was extremely female -intensive. In 1900 it employed 13,868 female hands (out of the total 19,463 male and female hands) which was 21.6 per cent of the total male and female employment in manufactories in the colony. The growth of female employment in the Victorian clothing industry was largely the result of the spread of the sewing machine, one of the most widely adopted inventions of the century. ${ }^{3}$ By comparison, New South Wales employed a much smaller number of hands and a much smaller percentage of its manufacturing workforce in this industry through the last quarter of the century. Hence it is this industry which is principally responsible for the fact that by the end of the century female employment in Victoria outnumbered that in New South Wales but male employment in the sector in New South Wales outnumbered that in Victoria, according to the official data published in the Statistical Registers.

Series of ad valorem or ad valorem equivalent tariff rates for the Clothing and the Boots and Shoes industries are reported in Columns (4) and (5) of Appendix Table 1. For the last five non-

\footnotetext{
${ }^{2}$ This is according to the official statistics reported in the Statistical Registers of the two colonies. There are differences between the definitions of employment in the manufacturing industries in the two colonies. Commentators believe the Victorian definition overstates the level of employment in that colony relative to that in New South Wales. Later estimates by Butlin and by Linge, reported in Vamplew (1987, p. 288), both show total employment in manufacturing Industries in New South Wales to be slightly less than that in Victoria.

${ }^{3}$ In the $19^{\text {th }}$ century these were treadle-operated machines that could be immediately set up in any location, factory or home. Isaac Singer patented the treadle-operated machine in 1851. Over the next two decades clothing factories using Singer machines and imitations of them sprang up in many countries.
} 
depression years of the Nineties, the (import-weighted) average tariff on all dutiable imports is around 30 per cent. These series need to be adjusted for components of the tariff rates on excisable products which are matched by excise taxes on the like item produced in Victoria - alcoholic beverages, and tobacco and tobacco products. The average excise-adjusted margin of protection in these years is around 25 per cent. Hence, the series for these two industries show they were subject to above average tariff protection in the last two decades of the century.

These increases in the levels of protection and employment in manufacturing industries in the colony of Victoria from 1866 onwards began the chain of events leading to the evolution of $19^{\text {th }}$ century tariff and wage protection.

\section{Wage Protection in the Colonies, 1850 to 1900}

Seltzer $(2015$, pp. 194, 197) observes that “...prior to the 1870 s there was very little union activity or government legislation of the non-convict labour market... Beginning in the 1870s, Australia increasingly turned to legislation as a way of controlling labour markets."

Regulation of labour markets in this era covered two areas: regulation of the working conditions, and regulation of wage rates (including piece rates). This regulation was concentrated on manufacturing industries, though there were important developments affecting the mining industries and shops too. Discussion below is confined to the manufacturing industries.

Historically the regulation of labour markets began with working conditions. Factory Acts regulated working conditions in factories or workrooms. It was in Victoria in 1873 that the first act regulating working conditions was passed, the Supervision of Workrooms and Factories Act. The conditions regulated were the hours of work for female workers and conditions relating to the number of persons in one room, warmth, ventilation, cleanliness and sanitation. Tasmania adopted regulations in 1884, South Australia in 1894, New South Wales and Queensland in 1896 and Western Australian in 1902. Regulations in these colonies followed closely the preceding regulations in Victoria.

Female workers were a particular target of these Acts. In Victorian manufacturing industries in the last quarter of the century, as noted in the previous Section, there was a rapid growth of female employment chiefly in the Clothing industry. The hours of work of women, but not of men, were restricted. The long hours and poor working conditions imposed on them were the subject of much debate in the popular press in Melbourne and in other cities such as Ballarat where these workers were located. (Serle 1971, chapter 3). 
One major concern was the use of "sweatshops" or "sweating." The term sweatshop is used by many writers to describe a workplace (or workroom in Victorian era parlance) where unskilled workers are employed under poor conditions and paid very low wages. In this era, the term had a more particular meaning. It referred to workplaces set up by middlemen who had obtained a contract for the production of certain goods. They were a subset of outworkers, almost all in the clothing and footwear industries, and mostly women and girls. Most of them had no other opportunities for work. In 1895 a group calling itself the National Anti-Sweating League was formed in Melbourne and campaigned for minimum wages for these workers.

In the regulation of wage rates, two different systems evolved. A Wages Board had the power to fix minimum wages or rates for designated workers. Such Boards existed in the colonies of Victoria and South Australia. A Conciliation or Arbitration Court, on the other hand, had powers to arbitrate labour market disputes when they arose, including the power to fix wage rates for workers in these disputes. Such Courts existed in the colonies of Victoria, South Australia, New South Wales and Western Australia. While the two systems are based on different ideological views of labour markets, they may co-exist, as they did in the colony of Victoria from 1891 and in that of South Australia from 1894.

The Victorian Factories and Shops Act 1896 introduced a system under which a Board could be appointed, if the Government wished, to fix minimum wage rates, including piece rates, for workers in four specified product groups or sub-industries. The groups were clothing or wearing apparel including boots and shoes, furniture, and bread making and baking. ${ }^{4}$ Minimum rates set were differentiated by gender, age and occupation ("trade"). Outworkers were covered as well as workers in a factory or workroom, and apprentices too. The primary purpose was to combat sweating in the clothing and the boots and shoes product groups but furniture was added because of concern over competition from Chinese-made ${ }^{5}$ furniture and bread making and baking because of concern over public health. This system was continued in the State of Victoria after federation and the coverage was extended to all factories and trades. Wages Board legislation was established by South Australia in the 1894 following closely the preceding Victorian legislation. In the colonial

\footnotetext{
${ }^{4}$ The 1896 Factories and Shops Act also imposed a minimum wage of $2 / 6$ per week for all factory workers. This was the first non-industry-specific minimum wage legislated in Australia but it affected only a small number of children as this rate was well below the rates for adult unskilled workers. The minimum weekly wage rate in Victoria in 1896 was £3.88 (Vamplew 1987, p. 155).

${ }^{5}$ That is, furniture made by ethnic Chinese workers. The industry was located in what is now known as China Town in the CBD of Victoria.
} 
period, the number of workers covered by the Boards rose rapidly after 1898 (Seltzer and Borland 2015, Figure 1).

In analysing this system, the traditional focus of labour economists is on the effects of the minimum rates on the levels of the wages and employment. These effects are difficult to estimate. Unlike regulation of imports by means of tariffs, where the international prices provide the benchmark prices that enables easy calculation of the effects of each tariff on domestic prices, there is no such benchmark wage rate in the case of labour market regulation. Wages rates are determined endogenously. Recently Seltzer and Borland (2015) found that the rates fixed by Boards raised wage rates, as measured by the ratio of the Lowest Minimum Wage to the Average Wage in the sample, substantially compared to modern times but these fixed rates had little effect on employment in the covered trades. Most of the cases they observed occurred in the period of federation.

Government regulation of wage rates by the alternative means of conciliation and arbitration began in the colonial era in Victoria with the Council of Conciliation Act 1891 and in New South Wales with the Conciliation Act 1892. These Acts provided for the appointment of Councils/Boards of Conciliation to which application might be made voluntarily by the parties involved in a workplace dispute and, if the dispute was not resolved and the parties agreed, they provided for the appointment of an arbitrator. The scope of the matters in a dispute which were subject to conciliation was far broader than that of the Wages Boards. It covered all industries and all industrial matters, both working conditions and wage rates and also the rights and duties of employees and employers. Nevertheless, the awards of the Councils/Boards could not be enforced by a court of law and hence were of little use in settling labour market disputes. Consequently, few Councils or Boards were appointed.

The first Act in the territory of Australia which provided for awards in industrial disputes that were binding on the parties and enforceable through the Courts was the South Australian Conciliation Act 1894. "Industrial matters" subject to awards related to "pay, wages, hours, privileges, rights, or duties of employers or employers ..." This Act enabled a party to be summoned before the Board of Conciliation, as in the proceedings of ordinary courts of law. All awards made by a Board of Conciliation were enforceable, with offences punishable by fines. The State Board had the power to undertake compulsory "conciliation" of any dispute when so directed by the President of the State Board; more accurately this provision was generally known as "compulsory arbitration". These provision for conciliation were not used much as the unions refused to register. This form of 
regulation became less important in South Australia than the Wages Boards. However, this Act was important as it set a number of precedents that were followed by Western Australia in 1900 and New South Wales in 1901 and later by the Commonwealth Conciliation and Arbitration Act.

This emergence of Wages Boards and Conciliation Boards was largely a response to the growth of union membership and activity. Craft unions emerged in Melbourne and Sydney after 1850.

Unions for less skilled and rural workers emerging later. Although the main objective of the unions in the 1860 s to 1880 s were the limitation of the working week to 48 hours, in the last quarter of the century unions were increasingly concerned with wage rates. Their demands were strongly resisted by employers who also challenged their demands for closed shops and even their right to exist. During the period of depression in the years 1890-94, the colonies on the East Coast of Australia were shaken by a series of strikes in the maritime, shearers and mining industries. These have been called the "great strikes". While the strikes were partly over pay rates, including demands from pastoralists in the 1891 Shearer's Strike in Queensland to cut nominal shearing rates, and working conditions, one issue dominated all of these strikes. This was what the employers called "freedom of contract", that is, the right to refuse to hire union labour. In his account of these strikes, Svensen (1995, p.1) concludes

\footnotetext{
"These disputes were all fought over the single issue of the refusal of some employers and managers to recognise labour unions as the legitimate bargaining agent for the workers they represented. These upheavals explain to a large extent why Australian and New Zealand came to adopt the distinctive industrial relations and political systems that have operated in those countries throughout the twentieth century."
}

Each of these strikes was broken.

After these setbacks, workers and unions turned increasingly to political action and sought election of their representatives to the colonial Parliaments. As a parliamentary party, the Labour Party dates from 1891 in New South Wales and South Australia. In all of the other colonies except Tasmania, a Labour Party had been formed and had candidates elected to the colonial parliaments by the time of federation. These colonial Labour Parties increasingly promoted compulsory arbitration and wagefixing by appointed boards as the means of achieving higher wages (see Shann 1930, chapter 21).

4. Tariff Protection and Wage Protection in the Early Commonwealth

By the time of federation, each of the six colonies had developed regimes of tariffs rates and of labour market regulations but the great variation in these regimes created a need for harmonisation. 
The constitution of the new Commonwealth gave exclusive power to impose tariffs to the Commonwealth and, under section 88 , required uniform rates across all States. In the area of labour market regulation, however, the Commonwealth government did not have exclusive powers and consequently there was no such constitutional requirement for uniformity among the laws of the States. Section 51(xxxv) empowered the federal Parliament to make laws respecting the conciliation and arbitration of industrial disputes which extend beyond the limits of any one State. There was a recognition that some harmonisation of the laws was required in this area too.

The debates in Parliament on these two items of foundation legislation were intense and occupied a large part of the debating time.

In the area of tariff policy, the Customs Tariff Act 1902 fixed the initial tariff rates. Lloyd (2015) estimates that the Commonwealth 1902 rates increased the average rate of customs duties on dutiable imports from other countries from about 13.1 per cent in 1900 to about 17.5 per cent in the Commonwealth. However, this increase was partially offset by the elimination of all tariff rates on inter-State (previously inter-colonial) trade. In the parliamentary debate, the Minister of Customs and Excise, who had the carriage of the Bill, declared "We recognize fully that at this time in our history neither free trader nor protectionist can have his say entirely. The Tariff is a compromise Tariff..." (Commonwealth Parliamentary Debates 1901-2, Vol. V, p. 5698). The Protectionist Party, which was the largest party in parliament and spurred on by the manufacturers, was quite dissatisfied with the level of these tariffs. This dissatisfaction led quickly to the establishment of a Royal Commission on Customs and Excise Tariffs.

On the second front of labour market regulation, the Commonwealth Conciliation and Arbitration Act 1904 established the Commonwealth system of regulation of these markets. The Bill was drafted and introduced to Parliament in the First Session of the First Parliament in 1901 but it was then withdrawn as a result of differences over the Labour Party's proposal for the Bill to cover State and Commonwealth public servants. It was introduced again in the Second Parliament by the South Australian Charles Kingston, a Minister in Deakin's first Government. This proposed legislation was supported by all three parties in principle, however, there were differences among them. The Labour Party had demanded that public servants employed by the States be covered, and they sought preference in hiring for union members. Kingston resigned from Deakin's Government over the opposition of some members of the Government to his attempt to impose conciliation and arbitration on British and foreign seaman engaged in the Australian coastal trade. After the Labour members withdrew their support for the bill, the government fell. The Labour Party formed its first 
Government, led by Chris Watson, but this lasted only four months. It was succeeded in August 1904 by a Government led by George Reid, leader of the Free Trade Party, and the Bill was then passed with the support of the Labour Party and some of the Protectionists.

The primary purpose of the Commonwealth Conciliation and Arbitration Act 1904 was to "prevent and settle industrial disputes" (section 16). Only disputes which extend beyond the limits of one State were within its jurisdiction but these were deemed in the Act to include "...disputes in relation to employment upon State railways and to employment in industries carried on by or under the control of the Commonwealth or a State or any public authority constituted under the Commonwealth or a State" (section 4). It established a Commonwealth Court of Conciliation and Arbitration, with a sole member, the President, who was to be appointed from the Justices of the High Court. It made a clear distinction between the settlement of disputes by means of facilitating an agreement between the parties or, if no agreement between the parties is reached, by means of the Court itself determining the outcome. The former is "conciliation" and the latter "arbitration".

Appendix Table 2 compares the main provisions of the Commonwealth Conciliation and Arbitration Act relating to the nature of industrial disputes before the Court with the corresponding provisions of the Acts of the four colonies (including New Zealand) that had binding legislation for industrial disputes in the colonial period. This table shows that Commonwealth Act is rooted firmly in the system that developed in the late colonial period. Every one of the listed provisions was laid down by preceding Acts of one or more of the colonies. The wording of the sections of the Act followed that of the colonial Acts.

The next major development was the introduction of New Protection Policy in 1906 by the second Deakin Government. This policy was set out in the Explanatory Memorandum prepared by the Deakin Goyernment for the Parliament (Commonwealth of Australia, 1907-08). This important document may be regarded as the official beginning of the New Protection Policy.

New Protection Policy was a declaration of the intention to raise protection in Australia. By this time the Labour Party had become firmly committed to a policy of protection and the Royal Commission on Customs and Excise Tariffs had reported, recommending an increase in customs rates. The Labour Party combined with Deakin's Protectionist Party to pass the Customs Tariff Act of 1908, the so-called Lyne Tariff. This 1908 Act was the triumph of the protectionists in Parliament over the free traders. It increased tariff rates on many items, particularly on woollen goods, iron and steel products and agricultural machinery. The average rate of duty on (actual) dutiable imports in the long-term series of Lloyd (2008, Table 5, Column 2) shows an increase from 
26.2 percent in calendar 1907 to 30.6 per cent in $1908 .^{6}$ This is about the same level as the average duty on dutiable imports in the colony of Victoria after the Victorian Customs Act passed in 1890 (see Appendix Table 1, column (3)). Moreover, the list of industries with above-average rates of protection is similar to that in the colonial Victorian tariff schedule.

New Protection Policy was much more than a declaration of a more protectionist policy. The Explanatory Memorandum declared

“The 'old' Protection contented itself with making good wages possible. The 'new' Protection seeks to make them actual. It aims at according to the manufacturer that degree of exemption from unfair outside competition which will enable him to pay fair and reasonable wages without impairing the maintenance and extension of his industry, or its capacity to supply the local market."

It then adds

"It does not stop here. Having put the manufacturer in a position to pay good wages, it goes on to assure the public he does pay them. This of course involves a careful adjustment of the duties to the double purpose they intended to serve. For that reason the proposals for the 'new' Protection include the establishment of permanent machinery for investigating and ascertaining whether the duties are really effective for those purposes. If they are, fair and reasonable wages must be paid. If they are not, the alternative is to alter the duties."

This policy clearly established a link running from "tariff protection" to "wage protection". This was the guiding principle of the new policy. ${ }^{7}$

\footnotetext{
${ }^{6}$ The new duties came into effect on 8 August 1907.

There was a rather confused debate in Parliament as to what the changes in hundreds of rates meant for the average tariff on imports (See the debate on the Second Reading of the Bill in Hansard, Vol. 43, 22/1/1908, pp. 7555-57.)

The Commonwealth Year Book of 1908, perhaps in response to the parliamentary debate, reports a detailed comparison of the 1902 and the 1908 Tariffs. It compares the revenue from tariff rates on actual imports in the year 1907, which were applied at rates under the 1902 Customs Tariff, with what it would have been if the rates in the 1908 Tariff had been applied to the imports of 1907. On imports of dutiable imports only, which is the measure to be preferred as an indicator of the level of protection, the average rate increased from 26.6 per cent to 33.0 per cent.

${ }^{7}$ Although this policy is associated with the Deakin Government in the federal period, La Nauze (1965, pp. 41011) traces the origin of the doctrine to the colony of Victoria in the last decade of the $19^{\text {th }}$ century. As a spokesman for the Protectionist Association, Deakin himself had stated the doctrine succinctly in the Victorian Legislative Assembly in 1895.
} 
The possibility of a link or links arises because the markets for goods and for labour are directly interrelated. Consider a group of importable products produced by a number of factories. Tariff protection increases the outputs and rates of profit of the owners of the factories producing the protected products. As employment increases with output, this would generally increase the wage rates of its employed labour. ${ }^{8}$ This link going from tariffs on the one hand to employment and wage rates on the other gives unions, as agents of the workers, an incentive to press politically for higher levels of tariff protection. Further, it could be argued that manufacturers who do receive tariff protection have an obligation to pay fair wages and to provide reasonable working conditions. This form of the link is the key feature of "New Protection" policy.

There is a second link in the reverse direction. An exogenous increase in wage rates, such as that resulting from the imposition of minimum wage rates above the actual market rates, will reduce output and profits of the factory owners. These losses may be recouped by an increase in tariff rates of the products produced.

While New Protection was described solely in terms of tariffs as the instrument of protection, the policy was also applied, quite logically, to other instruments of protection, or industry assistance as we call it today. Three Bounties Acts ${ }^{9}$ passed between 1907 and 1910 all made the payment of the bounties conditional on fair wage rates, expressed again in terms of wage rates "not below the standard rate". For many decades after Bounty Acts contained a provision that the payment of the bounty was conditional on payment by the recipient of fair and reasonable wages. Moreover, the government passed the Australian Industries Preservation Act $1906 .{ }^{10}$ This was aimed at the prevention of "unfair competition" from domestic monopolies and cartels established behind the tariff wall.

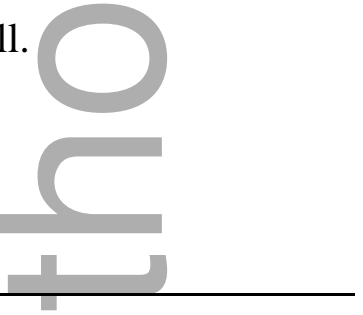

\footnotetext{
${ }^{8}$ However, in the limit case in which there is a perfectly elastic supply of labour, increased output would not increase the wage rate. The possibility of this case may have been the reason why sweated labour was common and why workers and unions in this period sought action to raise wage rates through legislation.

${ }^{9}$ They were the Bounties Act 1907 (which paid bounties on wool tops, dried fruits and some other agricultural products), the Manufacturers Encouragement Act 1908 (which paid bounties to producers of pig iron and iron and steel products) and the Shale Oil Bounties Act 1910 (which paid bounties on kerosene and paraffin wax).

${ }^{10}$ This was the third leg, as it were, of the social protection policy of New Protection which had been laid down in the Memorandum (Commonwealth of Australia, 1907-08, paragraph 16). However, "protection of the consumer" was secondary to the "tariff protection" and "wage protection" and developed much more slowly.
}

The Australian Industries Preservation Act also established for the first time in Australia anti-dumping actions against dumped imports of goods. This was a measure to counter "unfair" competition from other countries. 
New Protection Policy took a sharp twist in 1906 and 1907. In August 1906 the Tariff Commission ${ }^{11}$ had presented a report on the Agricultural Implements Industry. This had been referred to the Commission as a result of the threat of imports by the US company International Harvester. Following the recommendation of the Commission, Parliament raised tariffs rates on agricultural implements and machinery in the Customs Tariff Act of 1906. The Tariff Commission had also recommended that, in return for a higher tariff, manufacturers pay a "fair and reasonable" rate of wages and, if they failed to do so, the duties could be suspended after a joint Address from both Houses of Parliament. The Royal Commission on Customs and Excise Tariffs (Progress Report no.501907 pp. 4-5) had earlier made a similar proposal. As La Nauze (1965, p. 414) indicated "clearly this was clumsy: suppose one manufacturer paid "fair" wages and another did not?"

To circumvent this problem, the Government enacted a companion piece of legislation, the Excise Tariff Act 1906 (popularly known as the Harvester Act). This Act provided for the implementation of the link by means of a schedule of excise duties on domestic production of strip harvesters and other agricultural implements subject to tariff protection. To provide a substantial incentive for compliance, the excise duty rates were set equal to exactly one half of the tariffs on the corresponding goods. Such duties would be waived for an individual manufacturer when it proved that "fair and reasonable wages" were paid by it. A waiver was to be sought by application to the President of the Commonwealth Court of Conciliation and Arbitration. This was an unprecedented and administratively very cumbersome use of excise taxation.

The second President of the Conciliation and Arbitration Commission, Justice Higgins, took up his appointment in September 1907. He had immediately to consider 112 applications which had been referred to the Commission under the Excise Tariff Act 1906. As the test case for all of the applications, he selected that by H. V. McKay's Sunshine Harvester Company, one of the largest manufacturers of agricultural implements. Consequently, the case became known as the Harvester Case. In his Judgment, the President determined that a "fair and reasonable" wage for an unskilled male labourer in the industry was 7 shillings for an eight-hour day, or 42 shillings a week. This was his assessment of the wage that met "the normal needs of the average employee, regarded as a human being living in a civilized community". This employee had a family of "about five" persons. For other employees in the various trades employed in the industry, he laid down a schedule of

\footnotetext{
${ }^{11}$ The Tariff Commission was an advisory body set up by the Reid Government during the period of intense debate about tariffs. It made recommendations to the Commonwealth Parliament on tariff matters. Its powers were similar to the later Tariff Board but its members were selected to give equal numbers of free traders and protectionists. It operated only from 1904 to 1907.
} 
wage rates for each trade, based on the standard rates being actually paid in the labour market. These were deemed to be the "fair and reasonable" wage rates for the industry.

The 1907 Harvester Judgment introduced a principle of wage fixing which was new and seminal. In each of the applications examined by Justice Higgins, the standard rates applied to all employees, both single and married, and Australia wide. In subsequent cases before the Court, Justice Higgins refereed to the standard wage for an unskilled worker as the "living wage" and in a later 1916 case he renamed it the "basic wage" (10 Commonwealth Arbitration Reports 1916, p. 477). Although it was based on the principles of New Protection Policy, this application of the principle had not been anticipated.

After the Harvester Case, McKay and another Melbourne manufacturer refused to pay the Higgins standard wage rate or the excise duty in lieu of it and, after prosecution by the Commonwealth, the matter was referred to the High Court. In 1907 the High Court declared the Excise Tariff Act was unconstitutional, partly on the grounds that the legislation was essentially concerned with the regulation of employment conditions, a power that was not held by federal Parliament and one which could not be supported by the excise power. ${ }^{12}$

Notwithstanding this decision of the High Court, Justice Higgins applied the concept of a "living wage" in subsequent cases relating to industrial disputes that came before the Court of Conciliation and Arbitration. He did so in the very first case involving a dispute between employers and employees that came before him after his appointment, the Marine Cooks case of 1908. In Marine Cooks, Justice Higgins gave his reasons for adopting the "living wage" in an award concerning an industrial dispute:

"My function is to settle the dispute (sec.18); and, as incidental to this function, I have power to fix the minimum rate of wages to be paid to the employees of the different classes (se.40). No guidance is given as to the principles on which I am to act in settling a dispute nor in fixing wages; and I have to find out principles for myself. No doubt the issue is not precisely the same as that which I had to deal with in the Harvester case... and yet the same considerations are necessarily involved. I must settle the dispute on terms which seem to me just - on terms which I deem to be "fair and reasonable" between the parties. (3 Commonwealth Arbitration Reports, p. 60.)

\footnotetext{
${ }^{12}$ As Justice Higgins remained on the High Court during his term as President of the Conciliation and Arbitration Court, he also participated in the High Court decision on the Act. He was, with Justice Isaac Isaacs, one of the two voices dissenting against the majority High Court decision.
} 
This extension to cases involving an industrial dispute was the crucial step that made the concept of a "living wage" a major benchmark in the determination by the Court of Australian wage rates. Justice Higgins took this step because of his belief in "the need for a more positive state role in the economy" (Rickard, 1983) and his strong moral commitment to the principle of a living wage.

The extension of the principle was taken in spite of the fact that the original formulation of the "living wage" in the Harvester Case derived from the provision in the enabling Excise Tariff Act of 1906 that required workers employed in the sheltered agricultural implements industry receive "fair and reasonable wages." There was no such provision in the Commonwealth Conciliation and Arbitration Act. This Act merely directed the Court to settle disputes. In the event that no agreement be reached between the parties, the Court could settle the dispute by an award, which might include a specification of minimum wage rates. However, the Act, as noted by Justice Higgins, gave no guidance as to when minimum rates should be set or to how the minimum rates should be determined.

Justice Higgins remained the President of the Court until 1921, though Deputy Presidents were appointed from 1913. During this time, the "basic wage" became the central part of the Court's awards. (It was also adopted by State Wages Boards to industrial disputes outside the jurisdiction of the Commonwealth Court.) From 1913, Justice Higgins indexed the basic wage to the cost of living, using the Cost of Living index which the Commonwealth Statistician had just begun publishing in December 1912 This step initiated the unique Australian wage-setting system of a central Australia-wide basic wage determined by the cost of living with margins for skill, all determined by a Court. (For detailed accounts of wage-fixing by the Court, see Anderson (1929) and Hancock (2013)). This system continued for many decades, though the method of determining the "basic wage" and the relativities for other wage rates changed from time to time.

In this way, New Protection policy played a major part in the evolution of our system of labour market regulation. It was a system which was highly centralised and one which did not determine wage rates on the basis of the demand and supply of labour. The Court declared explicitly that the profitability of enterprises was not a factor taken into consideration in its determination of wage rates. In decisions reached after the Harvester Judgment, the President of the Court declared "The living wage must be kept as a thing sacrosanct - beyond the reach of bargaining; but when the 
skilled worker has been secured a living wage, bargaining may, with caution, be allowed to operate." 13

As a consequence of these operating rules, the wage rates fixed in awards were sometimes substantially in excess of those that would have applied in an unregulated market. In the seminal Harvester Case, Sunshine Harvester Company paid a wage rate of six shillings per day before the judgement, which was a relatively high wage rate, whereas the Court ordered a rate of seven shillings. . Justice Higgins himself later declared, in an oft-quoted passage, that his figure of seven shillings per day was well above prevailing market rates:

"I think I am close to the mark when I say, even for men in regular work, the average was not more than $5 \mathrm{~s} 6 \mathrm{~d}$ per day or $33 \mathrm{~s}$ per week. This would mean that the standard was raised by over 27 per cent." (Higgins, 1922, p. 97)

As the same standard of seven shillings for the minimum rate paid to unskilled male workers was used in later awards by the court in the time of Justice Higgins, with adjustment for changes in the cost of living, the Court raised award minimum rates above the prevailing market rates. However, I have found no estimate of the extent of these increases.

Under the Commonwealth Court of Conciliation and Arbitration, the system of labour market regulation quickly shifted from conciliation to arbitration, and arbitration became increasingly a determination of wage rates by the Court according to its own principles rather than a compromise solution to the dispute. "What began as a system for settling industrial disputes piecemeal became in the course of its early development an instrument for formulating and applying national wages policy." (Isaac 2008, p. 297). ${ }^{14}$

This wage-fixing system was generally accepted, though there were several legal challenges to the powers of the Court. Criticisms of the Court and its award were made generally by employers (Higgins 1922, pp. 29, 40). Unions quickly realised that they were receiving under the awards wages rates which they could not have received outside the federal Court. ${ }^{15}$ (The same applied to the State Wages Boards.) In the first five years of the application by the Court of Harvester wage

\footnotetext{
${ }^{13}$ For example these words are used in a major case, The Barrier Branch of the Amalgamated Miners' Association of Broken Hill v. The Broken Hill Propriety Company, 3 Commonwealth Arbitration Reports, 1909.

${ }^{14}$ A similar complaint was made in New Zealand. In 1901, six years after the passage of the New Zealand Act in 1894, one of its supporters found himself "driven by candour to admit that the system is not in any sense what it purports to be - a means of settling industrial disputes - and is rather a system for the regulation of the colony by means of ordinances (misnamed 'awards') issued by a court of law." (Quoted by Hammond, 1914, p. 100).

${ }^{15}$ Moreover, to be a party to a dispute before the Court, employees had to be registered with the Court as an "organisation", ie. a union. "The system of arbitration adopted by the Act is based on unionism." (Higgins 1922, p. 15).
} 
standards, union membership in Australia doubled; from 175,500 in 1906 to 364,700 in 1911 (Vamplew, 1987, p. 162). This may have been due to the growth of State awards, which covered many more workers than Commonwealth awards at this time, and other factors as well as the actions of the Commonwealth Conciliation and Arbitration Board.

Thus, by 1908, the legislation that laid the foundations of our laws and institutions regulating border protection of goods and labour markets had been passed and under the latter legislation, our wagefixing had evolved to the form that persisted for decades.

\section{How Tariff Protection and Wage Protection came about}

How did the federal legislation, after long and vigorous debates in the Parliament, end up following colonial precedents? And why did the Labour Party and the Labour Movement support tariffs which raised the cost of living of workers? And why did manufacturers and producers in other sectors accept a wage-fixing system which imposed higher wages costs on producers?

Over the period of the First and Second Commonwealth Parliaments, that is, from 1901 to 1906, there were only three parties in the Commonwealth Parliament; the Free Trade Party, the Protectionist Party and the Labour Party. The names of the first two parties indicate the primary role which the debate over tariffs played in the early Commonwealth Parliaments. None of the parties had a majority in either the First or Second Parliaments. It was a period of shifting coalitions in successive governments. In the first five years of the Commonwealth there were five Governments, with five different Prime Ministers and Ministries.

Two individuals played a prominent role in the construction of the foundation legislation, Alfred Deakin and Charles Kingston. Both were members of a colonial Parliament before federation. Alfred Deakin is the key political figure in this period. He was the second Australian Prime Minister. He was an ardent protectionist and a strong advocate of better worker conditions for workers in the colony of Victoria. As a Victorian he was a follower and friend of David Syme, the hugely influential Editor of The Age newspaper who promoted vigorously both the causes of protection and of better worker conditions for workers. In 1885, as the Minister responsible, Deakin secured the passage of the colony's second Factory Act and he was Treasurer of the National Anti-Sweating League after its formation. In the Commonwealth Parliament he was the leader of the Protectionist Party. While it originated as a single issue party, the Protectionist party also supported compulsory arbitration although its members were divided on Labour Party's demands for coverage over public servants and preference for union members. . It was in his first Ministry that the Commonwealth Conciliation and Arbitration Bill was introduced and in his 
Second Ministry that New Protection policies were introduced and enacted. Charles Kingston, then Premier of South Australia, shepherded the 1894 South Australian Conciliation Act. After federation, he drafted the Commonwealth Arbitration and Conciliation Bill. He has been called the "father of compulsory arbitration". As a member of Deakin's Protectionist Party, he also supported the cause of protection.

Notwithstanding the roles of these politicians, the early commonwealth legislation was driven by the interests of the major interest groups and their influences on the political parties. With regard to protection for manufacturing industries, employers in the primary industries, who were mostly exporters, and those in the service industries, which were at that time untraded, opposed the pleas of manufacturers for higher protection. Workers in the import-competing manufacturing industries, especially those in the less competitive labour-intensive industries, supported protection but other workers recognised the burden of higher prices for importable consumer goods. ${ }^{16}$ With regard to wage fixing and compulsory arbitration, workers and union supported this for all industries. Employers, however, were divided on the issue. Most were opposed but some employers, chiefly in the manufacturing industries, supported these labour market interventions in return for higher protection or as a means of reducing "unfair competition" due to competing tradesmen paying sweated or low wages (Macarthy, 1970). The Labour Party was initially divided and not committed to a protectionist line but it became protectionist with successive elections, as the Victorian Labour Party persuaded their New South Wales colleagues of the merits of New Protection. Labour Party support for higher tariffs was conditional on the introduction of compulsory arbitration.

This coincidence of interests led to a coalition of Deakin's Protectionist Party (representing the employers in the manufacturing industries) and Labour (representing the employees) which combined to pass both the Conciliation and Arbitration Act and the New Protection tariff legislation, the 1906 excise and tariff legislation for agricultural machinery and the 1908 Lyne Tariff. ${ }^{17}$ In effect, the political parties regarded these as a package. Macarthy (1970, p. 182) called

\footnotetext{
${ }^{16}$ This alignment of interests is confirmed by the modern specific-factor model of international trade developed by Jones (1971). This has two goods - an importable "manufacturing" good and an exportable "primary" good and three factors - a specific factor ("capital") in the manufacturing industry and a specific factor (which for this purpose is capital and land) in the primary industry - and a mobile factor, labour. Protection for manufacturing raises the real income of capital in the manufacturing industry and lowers that of land. The effect on real wages is ambiguous. It may raise or lower real wages, depending on the elasticity of demand for labour and the labour share of costs.

${ }^{17}$ Macarthy (1969 and 1970) gives an account of the political economy of labour legislation and tariff making in this period. Turner (1911) provides a very useful chronological account of the politics.
}

Macarthy also argues that this alliance of economic interests was accompanied by popular support for the fair treatment of sweated and low wage workers. This is what Castles (1988) called the movement towards "social protection". 
this "the 'unholy alliance' of Protectionists and labour in tariffs and wages legislation." (his italics). This is the link in the political sphere between wage protection and tariff protection.

When drafting the legislation in the Conciliation and Arbitration Act, it was natural for the drafters to go to the precedents of the South Australian legislation and those of New South Wales and Western Australia, which had accepted the principles of the South Australian legislation. The Federal bill was drafted by Charles Kingston, who had shepherded the earlier legislation through the South Australian Parliament. Similarly, when a coalition in Parliament had accepted the demands for higher protection, the higher tariffs of colonial Victoria, which had been cut by the 1902 Tariff, were the obvious target.

The manner in which the labour market legislation played out after its passage in Parliament is a different story. It is an instance of the influence of the views and actions of one man, Justice Higgins. In his earlier days as a member of the Victorian colonial Parliament, he had been a strong supporter of the anti-sweating legislation and of compulsory arbitration. At the Conventions preparing for the creation of the Commonwealth, he had been the mover of a resolution to include in the constitution a clause to give the federal government power to regulate "industrial disputes extending beyond the boundaries of any one state." (National Australasian Convention Debates, 1897, p. 782) The resolution passed at the second attempt. These same words were written into section 51 (xxxv) of the Australian Constitution. In 1907 Justice Higgins had accepted the request made to him by his fellow Victorian and Protectionist Party member, Prime Minister Deakin, to become the second President of the Court (Higgins 1922, p.175 and La Nauze 1965, pp. 414-19).

His Harvester Judgment, under the Excise Tariff Act, was a radical departure from previous practice. The extraordinary nature of Justice Higgins's method of determination of the wage rates in the applications which came before the Court can be seen when one compares it with that of his predecessor, the first President, Justice O'Connor. Like his successor as President of the Court, Justice Higgins, he was a member of the Protectionist Party in the Commonwealth Parliament before his appointment (where he was the leader of the Party in the Senate) and he was appointed to the High Court by Prime Minister Deakin. The first applications under the Excise Tariff Act came before the Court in his time. In re Bagshaw, he declared it was "impossible" for him to determine a wage rate which was "fair and reasonable" and instead he encouraged the parties in the each application to decide themselves what rate they could agree upon. 
After the Harvester Judgment, Justice Higgins went on to apply the principle of a living wage to awards in disputes that came before the Conciliation and Arbitration Court. He did so even though the legislation behind his Harvester Judgment was ruled unconstitutional by the High Court and even though there was no legislative backing for this method of wage determination. Again his action was a radical departure from that of the first President of the Court. In dealing with the two cases involving dispute over wage rates in his term, Justice O'Connor fixed award wage rates on the basis of the rates currently paid in the market with adjustments for the nature of the work. In the very first case to come before the Commission, the Merchant Services Guild Case of 1907 he stated the principles which should be used to determine the wage rates fixed in an award. After referring to the problems of sweated labour, he declared "Market value cannot be the only test - but market value must always be the most important element in any test which is to be applied." (1 Commonwealth Arbitration Reports, p. 25). The visiting American scholar, Mary Rankin (1916, p. 182) cites the latter part of this statement disapprovingly as a departure from free market wage rates but it is a far cry from the principles of a living wage later applied by Justice Higgins. In the same judgment, Justice Connor rejected the "living wage" as a basis of determining award wage rates whereas Justice Higgins disparagingly rejected the "higgling of the market."

\section{After the first two decades of the commonwealth}

There is one further link between wage protection and tariff protection. Although this occurs outside the period of the first two decades of commonwealth history covered by this paper, it illustrates how the links between tariff protection and wage protection continued beyond this period. After the Harvester Judgment, the processes of tariff fixing by Acts of Parliament and of wagefixing by the Court of Conciliation and Arbitration were independent of each other. Yet, in their application, there were interactions between them. The Tariff Board had been established in 1921 as an independent statutory authority to advise the Government on the tariff rates set by Parliament. In 1925 the Tariff Board noted "the growing tendency of employers and employees to pass from the Court of Conciliation and Arbitration, where wages may have been increased, to the Tariff Board, whence a recommendation for an increase duty may be made. " (Quoted in Castles, 1988, p. 95). It noted that wages were the largest element of costs. In its 1926 Annual Report the Tariff Board warned that "...passing back and forth between the federal Court of Conciliation and Arbitration and the Tariff Board for increments in wages and duties... [must] produce an ever increasing wage rate and an ever ascending tariff." These interactions can be interpreted as employers and workers using the systems of tariff fixing and wage-setting, which they had helped to create, to try to gain a 
marginal advantage; employers seeking higher tariffs when the Court raised wages and, similarly, the unions seeking to get a marginal wage advantage in the Court when tariffs were raised.

There is a similar question as to whether the State-level Boards that fixed wage rates were influenced by Tariff Board decisions. ${ }^{18}$ Reactions by State Wages Boards to Commonwealth Tariff Board decisions were delayed as the implementation of wage decisions required the establishment of specific Wages Boards. There have, however, been no studies of the relationship between decisions of State-level Wages Boards and those of the Tariff Board..

In labour markets, a centralised system of wage-fixing changes wage rates and wage relativities, both within and between industries. Before the 1920s there was little activity in the profession of economics in Australia. When Australian economists did start to comment on wage policy, they paid little attention to the effects of changes in wage rates and wage relativities on the allocation of resources in labour markets. Despite the novelty of the Australian system of wage regulation and the attention it received overseas, there was a total absence of empirical studies of labour markets. (Hancock, 2013, Chapter 13 provides a comprehensive survey of economic opinion on wages policy up to World War II). Australian economists in the 1920s and 1930s generally accepted the outcomes of an increasingly centralised system. ${ }^{19}$ Attention was focussed instead on the level of the minimum wage, wage indexation and the capacity to pay (see again Hancock, 2013, Chapter 13). ${ }^{20}$ Since World War II analyses by Australian economists of labour market distortions due to government interventions has been carried out separately from analyses of the costs of product market distortions due to tariff protection. The link between tariff protection and wage protection collapsed. For product markets, the Tariff Board in the first 40 years of its existence had examined levels of protection for narrow individual product groups - which Corden (1963, p. 177) described as the "made-to-measure" approach to tariff policymaking. This fostered the interactions with the Conciliation and Arbitration Commission noted above. From the 1960s, however, concern in the Tariff Board and elsewhere shifted to the general industry structure of protection. Similarly, in labour markets, the focus of the shifted to economy-wide wages and employment policies.

\footnotetext{
${ }^{18}$ A referee drew this to my attention.

${ }^{19}$ By contrast, contemporary commentary by British and particularly American economists was much more critical of the "Australian" system of wage -fixing and especially of compulsory arbitration; see, for example, Hammond (1914) and Rankin (1916).

${ }^{20}$ Another important set of questions is the effects of growing Australia-wide wage fixing on the macroeconomy: on the level of national unemployment, national output, prices, productivity and other macroeconomic variables. Macroeconomic effects of wage-fixing became more important in the 1920s and 1930s as the coverage of the commonwealth system expanded.
} 


\section{Summary}

After federation, the institutions and basic methods used to regulate international trade in goods and labour markets in Australia had been laid down by the end of the first decade. The particular forms of the institutions and laws which governed these interactions were based closely on precedents set in the late colonial period.

In the political sphere, a coalition of the Protectionist Party and the Labour Party combined to pass both the Conciliation and Arbitration Act and the New Protection legislation. In the regulatory systems themselves, there was another important link through New Protection Policy which sought to ensure that the producers who received protection paid fair and reasonable wages. New Protection Policy had a major influence on the hugely important Harvester Judgment of the Court of Conciliation and Arbitration. This link was used by the Conciliation and Arbitration Court to justify wage rate regulation. Later there was a further link between the tariff levels recommended by the Tariff Board and the awards of the Court of Conciliation and Arbitration.

All of these links were fundamentally the result of the interdependence between the markets of produced goods on the one hand and the markets for labour employed in the production of those goods on the other. They produced institutions and regulatory methods that were unique to Australia and they made these markets in the Australian economy among the most highly regulated markets in the non-communist world for many decades.

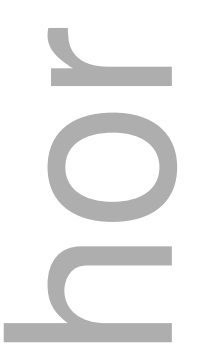

\section{References}

Anderson, G. (1929) Fixation of Wages in Australia (Melbourne: University of Melbourne Press).

Borland, J. (2015) "Microeconomic Reform" in S. Ville and G. Withers (eds). The Cambridge Economic History of Australia (Port Melbourne: Cambridge University Press), pp. 419-437.

Brigden, J. B., D. B. Copland, E. C. Dyason, L. F. Giblin and C. H. Wickens (1929) The Australian Tariff: An Economic Enquiry (Melbourne: University of Melbourne Press).

Castles, F. (1988), Australian Public Policy and Economic Vulnerability. A Comparative and Historical Perspective (Sydney: Allen and Unwin). 
Coghlan, T. A. (1918) Labour and Industry in Australia: From the First Settlement in 1788 to the Establishment of the Commonwealth in 1901 (London: Oxford University Press).

Commonwealth Conciliation and Arbitration Commission (various) Commonwealth Arbitration Reports.

Commonwealth of Australia (various) Commonwealth Parliamentary Debates (Hansard).

Commonwealth of Australia (1906, 1907) Reports of the Royal Commission on Customs and Excise Rates. Parliamentary Papers (Melbourne: Commonwealth of Australia).

Commonwealth of Australia (1907-08) "New Protection - Explanatory Memorandum in Regard To", Parliamentary Papers, II, pp. 1887-79.

Corden, W. M. (1963) “The Tariff” in A. Hunter (ed.), The Economics of Australian Industry (Melbourne: Melbourne University Press).

Hammond, M. B. (1914) "Wages Boards in Australia I: Victoria”, Quarterly Journal of Economics, 29 (1), pp. $98-148$.

Hancock, W. K. (1930) Australia (Brisbane: Jacaranda).

Hancock, K. (1933) “The Commonwealth, 1900-1914” in E. Scott (ed.), Cambridge History of the British Empire, vol. VII, Part I (Australia) (Cambridge: Cambridge University Press), pp. 491-520.

Hancock, K (2013) Australian Wages Policy: Infancy and Adolescence (Adelaide: University of Adelaide Press).

Higgins, H. B. (1922) A New Province for Law and Order (London: Constable and Co).

Fenna, A. (2012) "Putting the 'Australian Settlement' in Perspective”, Labour History, 102 (May), pp. 99118.

Isaac, J. (2008) “The Economic Consequences of Harvester”, Australian Economic History Review, 48 (3), pp. 280-300.

Jones, R. W. (1971) “A Three-factor Model in Theory, Trade and History” in J. N. Bhagwati et al (eds),Trade, Balance of Payments and Growth (Amsterdam: North Holland).

Kelly, P. (1992) The End of Certainty (Crows Nest, N.S.W: Allen and Unwin).

La Nauze, J (1965) Alfred Deakin: A Biography (Melbourne: Melbourne University Press). 
Lloyd, P. J. (2008) "100 Years of Tariff Protection in Australia”, Australian Economic History Review, 48, July, pp. 99-145.

Lloyd, P. J. (2015) “Customs Union and Fiscal Union in Australia at Federation”, Economic Record, 91, June, pp. 155-171.

Lloyd, P. J.(2016), “The First 100 Years of Tariffs in Australia: the Colonies”, Australian Economic History Review (forthcoming).

Macarthy, P. (1969) "Labour and the Living wage, 1890-11910", Australian Journal of Politics and History, $13(1)$, pp. 67-89.

Macarthy, P. (1970) "Employers, the Tariff and Legal Wage Determination in Australia - 18901910”, Journal of Industrial Relations, 12 (2), pp. 180-93.

Macintyre, S. (2009) “What Happened to Deakinite Liberalism?" in P. Strangio, P. and N. Dyrenfurth (eds.), Confusion: the Making of the Australian Two-Party System (Carlton: Melbourne University Press), pp. 227-248.

National Australasian Convention Debates (1897) Official Report (Adelaide: Government Printer).

Patterson, G. D. (1968) The Tariff in the Australian Colonies 1856-1990 (Melbourne: Cheshire).

Rankin, M. T. (1916) Arbitration and Conciliation in Australasia: The Legal Wage in Victoria and New Zealand (London: G. Allen and Unwin).

Rickard, J. (1983) "Higgins, Henry Bourne (1851-1929)”, Australian Dictionary of Biography, volume 9 (Melbourne: Melbourne University Press). (Electronic resource).

Seltzer, A. (2015) "Labour, Skills and Migration" in S. Ville and G. Withers (eds), The Cambridge Economic History of Australia (Port Melbourne: Cambridge University Press), pp. 178-201

Seltzer, A. and Borland, J. (2015) "The Impact of the 1896 Factory and Shops Act on Victorian Labour Markets", mimeo. (The University of Melbourne).

Serle, G. (1971) The Rush to be Rich Melbourne (Melbourne University Press).

Shann, E. O. G. (1930) An Economic History of Australia (Melbourne: Cambridge University Press). 
Shann, E. O. G. (1933) “Economic and Political Development” In: E. Scott, ed., Cambridge History of the British Empire, vol. VII, Part 1 (Australia) (Cambridge: Cambridge University Press), pp. 296-323.

Strangio, P. and N. Dyrenfurth (eds.) Confusion: the Making of the Australian Two-Party System (Carlton: Melbourne University Press).

Svensen, S. (1995) Industrial War. The Great Strikes 1890-94 (Wollongong: Ram Press).

Turner, H. G. (1911) The First Decade of the Australian Government: A Chronicle of Contemporary Politics, 1901-1910 (Melbourne: Mason, Firth and M'cutcheon).

Vamplew, W. (ed.) (1987) Australian Historical Statistics (Broadway: Fairfax, Syme and Weldon).

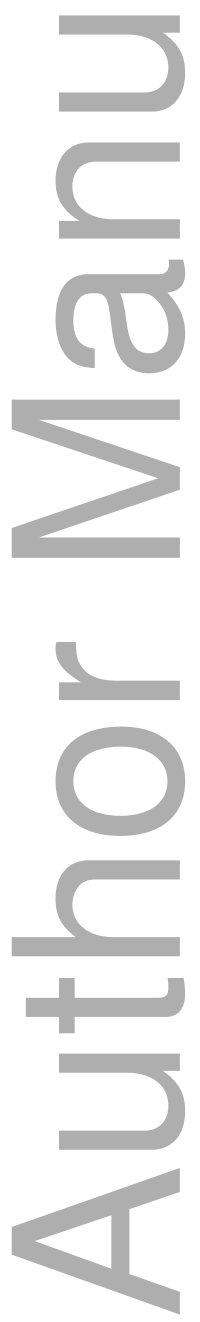




\section{University Library}

\section{- M M N E R VA A gateway to Melbourne's research publications}

Minerva Access is the Institutional Repository of The University of Melbourne

Author/s:

Lloyd, $P$

Title:

The Evolution of Tariff Protection and WageProtection in the Late Colonies and Early Federation

Date:

2017-12-01

Citation:

Lloyd, P. (2017). The Evolution of Tariff Protection and WageProtection in the Late Colonies and Early Federation. ECONOMIC PAPERS, 36 (4), pp.459-476. https:// doi.org/10.1111/1759-3441.12183.

Persistent Link:

http://hdl.handle.net/11343/293207 